\title{
A sociolinguistic study of language contact, shift, and change*
}

\author{
RAYMOND MOUGEON, EDOUARD BENIAK, and DANIEL VALOIS
}

\begin{abstract}
Bilingual speech communities provide linguists with a favorite laboratory to study the effects of language contact on linguistic structure. Without denying the interest or importance of this traditional contrastive approach to the problem of bilingualism, attention is attracted to the often concomitant problem of language shift and to the linguistic consequences of the resultant restriction in subordinate language use: grammatical simplification and stylistic reduction. These internal developments, but also external ones due to language contact, are examined through the multiple variants of a prepositional variable in Ontarian French, a contact variety of Canadian French whose speakers evidence varying degrees of knowledge of and shift to English. It is shown that even a high level of retention of French is not a safeguard against grammatical influence from English, any more than maintenance of French on a par with English is a guarantee against simplification. This suggests that in a situation of UNSTABLE bilingualism, speakers may be unable to preserve the structural 'integrity' of the subordinate language.
\end{abstract}

\section{Introduction}

Contact situations where a bilingual community is undergoing language shift have been discussed under a variety of headings in the literature, for example language death (Dorian 1981), minority languages (Giacalone Ramat 1979), immigrant languages (Haugen 1969), language shift (Gal 1979), etc. Notwithstanding the different labels, all of these contact situations are alike in two essential respects: (1) the population undergoing shift is in the minority demographically; (2) the language being shifted to enjoys wider currency and greater prestige. Contact situations of this kind, involving shift to a superordinate language, 
typically yield a continuum of subordinate language speakers who are more or less advanced on the shift path. By taking the speech of those who show a high degree of retention of the subordinate language as a bench mark, it becomes possible to ascertain what effects varying levels of restriction in subordinate language use (from pronounced in the case of the infrequent users of the subordinate language to relative in the case of the roughly equal users of the languages in contact) have on the linguistic form of the subordinate language. It is expected that restriction in language use results in imperfect learning and thus simplification.

Research on how restriction in language use impacts on linguistic structure would seem to represent a somewhat 'refreshing' approach to the problem of bilingualism with language shift to the extent that it breaks with the tradition of contrastivism which has characterized research on language contact. Nevertheless, because restriction in language use implies CONTACT with a displacing language, it follows that research on language restriction also allows one to examine the question of the linguistic influence of one language on another. In this connection, it has been claimed by Poplack (1981) that Puerto-Rican Spanish in New York City has preserved its structural integrity (i.e. shows stiff resistance to grammatical influence from English) despite widespread bilingualism among the Spanish-speaking population. It is her belief that bilingualism in itself (unless of course it goes as far as dominance in the superordinate language) should not adversely affect the grammar of the minority language, provided the latter is holding its own against the superordinate language in a situation of stable bilingualism.

The French language as it is spoken in the Province of Ontario, Canada, lends itself both to research adhering to the traditional contrastive approach to language contact and also to research on the effects of language restriction per se on linguistic form to the extent that the Franco-Ontarian sociolinguistic situation is one of bilingualism with shift to the language of the majority, English (cf. section 1). In the present study we will examine a rather complex case of variability in the prepositional subsystem of this regional variety of Canadian French (cf. section 3). The variable expresses the notions of movement to/location at a person's dwelling and is realized by two types of variants: the simple prepositions chez, sur, and $\grave{a}$ (for example, je suis chez moi 'I'm at home') and prepositional phrases involving the noun maison (for example, je vais à la maison 'I'm going home'). Its interest lies in the fact that through its variants may be seen operating the different effects that language contact (i.e. bilingualism) and language shift (i.e. restriction in language use) have been observed to have on linguistic form, both in our own research and in 
that of others: (a) simplification (Giacalone Ramat 1979; Dorian 1981: chapter 4; Mougeon and Beniak 1981; Trudgill 1983: chapters 5 and 6), (b) loss of ability to shift styles (Gal forthcoming; King 1984) and even total loss of stylistic options (Beniak and Mougeon 1984), and (c) interlingual influence, which for the purposes of the present study may be subdivided into convergence (Gumperz and Wilson 1971; Beniak et al. 1984/1985) and interference (Weinreich 1968; Beniak et al. 1981). It will be seen that interlingual influence is far from easy to prove when there are (and there usually are) competing internal explanations for the suspected cases of transfer (cf. section 5), a fact which has inclined Andersen (1982: 108) to opine, as regards morphosyntactic transfer, that it is 'ONLY POSSIBLE in those cases where both forces internal to the language... and forces traceable to transfer co-exist' (his emphasis). It will also be seen that whereas Puerto-Rican Spanish has purportedly maintained its grammatical integrity, the same cannot be said of Ontarian French, suggesting that the distinction between stable and unstable bilingualism is crucial when it comes to predicting the likelihood of grammatical influence - and, we want to add, simplification as well (cf. section 6).

In a different vein, synchronic variation is usually not studied within an historical perspective, and so one is very often left in the dark concerning when and how the variants arose in the course of the language's history. ${ }^{1}$ In this study we will trace back the different variants within the recorded history of the French language (cf. section 4). It will be seen that two of the variants (chez and sur) admit alternative explanations to those that have traditionally been proposed to account for their origins. Another interesting finding to emerge from the historical examination will be that two other variants ( $\grave{a}$ and $\dot{a}$ la maison $d e$ ), both of which are attested during the earliest stages of the language, are actually not the result of uninterrupted transmission from Old French to the present but innovations due to the instability of the bilingual situation. Their synchronic social distribution will be shown to confirm their discontinuous history (cf. section 5).

In short, via an examination of a case of multiple variation in a contact variety of French whose speakers are undergoing shift to English, this paper proposes to illustrate what happens to language structure under conditions of restricted language use, without for all that neglecting to consider the effects of bilingualism proper on linguistic structure. The paper's added modest contribution to French philology should also make it of interest to historical linguists. Before describing our methodology (cf. section 2), a minimum of background information on Ontario's Frenchspeaking population is in order. 


\section{Ontario's French-speaking community}

According to the 1981 national census of Canada there were that year 475,605 people of French mother tongue in the Province of Ontario out of a total population of $8,625,105 .^{2}$ Though Franco-Ontarians were numerically the largest of Canada's French-speaking minorities, it can be calculated from the above figures that they represented under $6 \%$ of the provincial population. At a local level, however, the ratio of Francophones to Anglophones varies considerably from lows that come close to $0 \%$ to highs that reach $80 \%$ or $90 \%$ of the population. Special analysis of the previous decennial census returns (i.e. 1971) revealed that Francophones are not as well off as Anglophones in Ontario. The inferior demographic and socioeconomic position of Ontario's Francophones as well as the lack of schooling in French at the secondary level prior to 1968 (see below) are three important factors which help explain why out of the 475,605 who reported French as their mother tongue in 1981, only 307,290 reported French as their principal home language. These figures indicate that a substantial proportion of Ontario's French mother tongue population has shifted to English at home. However, just as the ratio of Francophones to Anglophones varies locally, so does the degree of language shift at home.

In 1968 the Ontario Legislature finally legalized French as a language of instruction in Ontario's public schools. This much belated measure brought about the foundation of public French language high schools which together with the primary schools already in place in the separate (i.e. Catholic) school system provided schooling in French from kindergarten to grade 13 in most Ontarian localities where nonnegligible numbers of Francophones reside. (See Vallières 1980: 163-195 for a brief history of the Franco-Ontarians' drawn-out struggle for schooling in their own language.) At the time this measure was taken it was hoped that it would slow down if not stop the process of shift to English at home. For the time being, however, Ontario's French language schools continue to include students who come from homes where English is spoken as often as or even more often than French. ${ }^{3}$

\section{Methodology}

In the late 1970s the Centre for Franco-Ontarian Studies was contracted by the Ontario Ministry of Education to do a survey of the francophone students' retention of French (vs. shift to English) as revealed by their language use patterns and to relate these patterns to their proficiency in 
spoken French. The corpus on which our sociolinguistic research is based is drawn from that earlier survey (cf. Mougeon et al. 1982). It consists of samples of spoken French obtained via tape-recorded interviews with 117 Franco-Ontarian adolescents enrolled in French language high schools situated in various localities across the province. The interviews lasted from about 30 minutes to an hour and aimed at tapping an unreflecting style of speech approaching the students' vernacular. Sociological data were gathered via questionnaire prior to the interviews and comprise information on, among other things, the interviewee's sex, socioeconomic background, frequency of use of French (vs. English), and locality of residence. Sex and socioeconomic background were controlled since both are traditional social parameters in sociolinguistic research. Socioeconomic background was determined on the basis of the occupation of the father or of the mother, whichever was higher. Three socioeconomic backgrounds were distinguished: middle (i.e. professionals or semiprofessionals such as doctors, lawyers, teachers, etc.), lower-middle (i.e. small store owners, office workers, self-employed craftsmen, etc.), and working (i.e. skilled and unskilled workers).

Frequency of use of French was controlled under the two-fold assumption (a) that restriction in use would lead to imperfect learning and hence to simplification and (b) that knowledge of and shift to English, the other side of the coin, would result in interlingual influence. At the time we constituted our corpus there was already growing empirical support for these assumptions from various bilingual settings, such as language death (Dorian 1977), immigrant languages (Karttunen 1977), and minority languages (Giacalone Ramat 1979). Information on the students' language use patterns was gathered via self-reports focusing on a variety of informal situations involving familiar interlocutors: interaction with parents, siblings, and peers at home, with siblings and peers outside the home, and with peers at school in the classroom and corridors. The students were asked to rate their language use on a five-point scale ranging from always in French to always in English. The students were also asked to provide information on their parents' frequency of use of French with each other and with them, again using the same five-point rating scale. All of this information was eompiled to arrive at individual indices of frequency of use of French for interpersonal communication with interlocutors well known to the speaker. The indices thus obtained ranged from 1 or exclusive use of French to near 0 or almost exclusive use of English. The reader should bear in mind that a very low index (the lowest was .05 ) does not signify English monolingualism since all of our subjects were schooled in French. ${ }^{4}$ We were satisfied that all were sufficiently 
fluent in French to go through a semistructured interview situation without too much difficulty. For the purposes of the present paper we distinguished three levels of frequency of use of French: high (.80-1.00), mid (.45-.79), and low (.05-.44). We should also point out that to guard against including non-Francophones in our sample, each student had to have at least one parent of French mother tongue. Still, the vast majority of our subjects came from non-mixed-marriage households.

Finally, since we selected speakers residing in four different localities, we decided to control this factor as well with a view to possibly capturing geographical variation (cf. Mougeon et al. 1981). A speaker was deemed to be representative of the speech of his locality if he had resided there at least since the age of eight or not more than midway through what may be considered the 'formative period for a native speaker' (cf. Labov 1972: 304-305). The localities in which our speakers were selected, along with their population and francophone concentration, are the following: Hawkesbury ( 9877 inhabitants of which 8355 or $85 \%$ are Francophones), Cornwall ( 46,144 inhabitants of which 15,965 or $34 \%$ are Francophones), North Bay ( 51,268 inhabitants of which 8545 or $17 \%$ are Francophones), and Pembroke $(14,206$ inhabitants of which only 1185 or $8 \%$ are Francophones). ${ }^{5}$

A limitation of our corpus is that since it is not constructed with an 'apparent time' dimension, we will not be able to say anything about whether the case of linguistic variation under study is stable or a change in progress (cf. Labov 1981: 177-199). Nonetheless, as others have done, we might still wish to speak of change in at least two other senses: in the sense of departure from an external standard monolingual norm (cf. Trudgill 1976-1977) or in the sense of departure from an internal community norm (cf. Haugen 1977). In a bilingual setting such as the one we are investigating, the internal community norm or bench mark would be that which the speech of the high-frequency users of French embodies, that is, the most 'conservative norm' in Dorian's words (1981: 116). It is in this second sense that we will be employing the word 'change' in this paper when referring to the Franco-Ontarian sociolinguistic situation. As Trudgill (1983: 124-125) himself acknowledges, the first criterion for establishing change seems less than satisfactory since there is no telling whether the external colloquial monolingual norm does not itself exhibit the same departures from the standard as does the contact variety. Worse still, when the contact varicty has had a prolonged independent existence (as is the case of Arvanitika, the Albanian dialect of Greece studied by Trudgill), to take the noncontact variety (i.e. mainland Albanian) as the norm of comparison is all the more unwarranted (cf. Dorian n.d.). 


\section{The variable}

As indicated, the variable under investigation is composed of an assortment of prepositions and prepositional phrases via which the idea of location at/movement to a person's dwelling may be expressed in Ontarian French. For now let us say that we found four (later we will see that it is really five) different manifestations of the variable in the computerized alphabetical concordance of the interview transcripts: the prepositions chez, sur, $\grave{a}$, and the prepositional phrase à la maison de ${ }^{6}$

The first step in any variation study should be to examine the linguistic distribution of the variants in order to make sure that they are indeed substitutable and not in complementary distribution (cf. Thibault 1979: 3 ). At the same time this exercise will serve to familiarize the reader with the different variants, all of which will be illustrated by a series of examples drawn from our corpus. The ideal situation would be one where the speakers actually produced minimal pairs, but one cannot as a rule expect such evidence when dealing with nonphonological variables. We will examine the distribution of the variants with respect to two features of the linguistic context which immediately suggest themselves as potential conditioning factors: the verb (static vs. motion) and the complement (noun vs. pronoun). Let us begin with the variant chez:

(1) a. Pis on est allé heu ... chez ma grand-mère.

'And we went uh ... to my grandmother's.'

b. J'étais chez mon cousin.

'I was at my cousin's.'

c. Tout le monde vient chez nous.

'Everyone comes to our house.'

d. Y'étaient pas chez eux.

'They weren't home.'

Chez is a variant which corresponds to standard usage and whose frequency of occurrence was highest of all of the variants (166 tokens). As the above examples show, chez is both locative and directional and can introduce either a nominal or pronominal complement referring to a person. Other pronouns besides personal ones are possible (for example, indefinite pronouns such as quelqu'un 'someone') but are far less frequent and in any case they too (notwithstanding their name) refer to a person.

Sur, on the other hand, is a nonstandard variant, and it occurred only infrequently in our corpus ( 8 tokens):

(2) a. Quand qu'on va $s u(r)$ nos oncles. ${ }^{7}$

'When we go to our uncles'.' 
b. Moi j'restais $s u(r)$ ma cousine.

'I was staying at my cousin's.'

c. '?*uand qu'on va $s u(r)$ eux.

'When we go to their house.'

d. ?*Moi j'restais $s u(r)$ elle.

'I was staying at her house.'

Examples (2a) and (2b) are in every respect analogous to (1a) and (1b). They show that sur, like $c h e z$, can indicate location at and direction to a person's home. But we failed to note any occurrence of sur with a personal pronoun $(2 \mathrm{c}, 2 \mathrm{~d})$. We do not think that this is simply an artifact due to the low frequency of sur, because Seutin (1975: 345 346) also reports that sur never cooccurs with personal pronouns in the spoken French of L' ̂lle-aux-Coudres (down-river from Quebec City on the Saint Lawrence), where it is a much more common variant of chez. Be that as it may, chez is not confined to pronominal complements and so the two prepositional usages cannot be said to be in complementary distribution.

$\grave{A}$, also a nonstandard and infrequent variant (only 8 tokens), is distributed just like sur:

(3) a. J'été à mon grand-père.

'I went to my grandfather's.'

b. J'ai resté là pour une coup'e de journées $a ̀$ mon grand-père.

'I stayed there for a couple of days at my grandfather's.'

c. ?J'été à lui.

'I went to his house.'

d. ?J'ai resté là pour une coup'e de journćes à lui.

'I stayed there for a couple of days at his house.'

It may be seen that $\grave{a}$ can cooccur with a motion verb or with a static verb and that it was never found introducing a personal pronoun. The literature is not of help this time in weighing the plausibility of such a categorical constraint since none of the works on contemporary or past varieties of Canadian French attest $\dot{a}$ as a variant of $c h e z .{ }^{8}$ This in itself is a significant observation which we will return to in the historical section.

Matters are a bit more complex when it comes to the prepositional phrase à la maison de. Indeed, it hides a certain amount of complementary distribution as well as 'free' variation. À la maison de remains as is before a noun (as in examples [4a] and [4b]) but surfaces as $\grave{a}+$ det. + maison when the complement (in underlying structure) is a personal pronoun (as in examples [4d]-[4h]). We might wish to call à la maison de and $\dot{a}+$ det. + maison 'allophrases' because of their complementary distribution. However, and this is where the complication arises, $\grave{a}+$ det. + maison is 
realized equivalently as $\grave{a}+$ poss. adj. + maison or as à la maison when the underlying personal pronoun is coreferential with an intrasentential antecedent (practically always the sentential subject as in examples [4c] and [4e]) or has as its referent the speaker (as in examples [4d] and [4f]). The absence of a possessive marker in à la maison corresponds to the wellknown tendency in French not to overtly mark inalienable possession, of which a person's dwelling must be presumed to be an instance. When the underlying pronoun has an extrasentential antecedent or when it does not refer to the speaker, possession must then be overtly marked as illustrated in examples $(4 \mathrm{~g})$ and $(4 \mathrm{~h})$ :

(4) a. On se rencontre à la maison de mon ami.

'We get together at my friend's house.'

b. ?On est allé à la maison de mon ami. ${ }^{9}$

'We went to my friend's house.'

c. Une fois arrivé à sa maison y'a ....

'Once he arrived home he ....'

d. Elle voulait rester à notre maison.

'She wanted to stay at our house.'

e. Elle travaille à la maison.

'She works at home.'

f. I' viennent à la maison.

'They're coming to our house.'

g. Quand j'vas à leur maison.

'When I go to their house.'

h. ... à (la) place de moi aller à sa maison.

'... instead of my going to his house.'

In view of the above, having initially distinguished nominal from pronominal complements, we must now distinguish the latter (personal pronouns) according to the (co)reference relations into which they enter: those that refer to the speaker or are used coreferentially with an intrasentential antecedent (PROi) and those for which neither is true (PRO), remembering that the pronouns are present only at a deeper level of structure. On the grounds that à la maison (a) alternates with $\grave{a}+$ poss. adj. + maison in the context of PROi, (b) is the only one of the three prepositional phrases which is considered correct usage here in Canada (cf. Bélisle 1974: 733) as well as in France (cf. Robert 1972: 1026; Larousse 1966: 699), and (c) displayed a frequency of occurrence in our corpus (69 tokens) far outweighing that of the other prepositional phrases (only 6 tokens of $\grave{a}+$ poss. adj. + maison and 2 of à la maison de), we decided, in the final analysis, to set up à la maison as a variant separate from $\grave{a} l a$ maison de, the latter having the allophrase $\dot{a}+$ poss. adj. + maison. 
In ending this section, we wish to reiterate that all we have done to this point is consider the possibility of categorical constraints bearing on the use of the different variants. This was necessary in order to make sure that we were dealing with genuine variation and not complementary distribution. Although we did find evidence of complementary distribution, it was purely internal to the prepositional phrase $\dot{a}$ la maison de and in no way called into question à la maison de's status as a true variant of the simple prepositions $c h e z$, sur, and $\dot{a}$. In a later section, when we analyze the data quantitatively, we will be able to see whether any weaker constraints or tendencies obtain. It will probably help the reader visualize the variable better if we represent it as in Figure 1.

\section{History of the variants}

Without disagreeing with Saussure (1967: 114-150) that diachrony and synchrony are best kept completely separate, by which we mean, as Kiparsky (1980: 411) has written, that 'the role of an element in the linguistic system is something in principle absolutely independent of its historical origin', we will try to show that historical information may be suggestive of synchronic explanations that the linguist would (and could) otherwise never have considered. Moreover, our intention here is not merely to report facts concerning the variants' historical origins and evolution but to question some of the interpretations that have been made of these facts.

\subsection{Chez}

This preposition is attested for the first time in the 12th century in examples like chies un hoste 'at a host's' or ches son hoste 'at his host's' (cf. Littré 1968a: 264; Wartburg 1940: 450). Chies (or ches) was the atonic form of the noun chiese (or chese) 'house' ( $<$ Vulgar Latin casa 'house') (cf. Greimas 1968). It was normal for word-final $a$ to reduce to schwa as in casa $>$ chiese (or chese). That the vowel dropped altogether in chies (or ches) is probably due to the atonic position of the word (cf. Nyrop 1899: 209). According to Wartburg (1940: 452), casa was replaced very early by mansio 'house' (> maison) in Gallo-Romance, especially in the North. But traces of casa in Old French are said to be seen in examples like en chies son hoste 'at his host's house' or a ches nos 'at our house' (cf. Nyrop 1899: 95). In fact, Nyrop suggests that the preposition chies (or ches) emerged as a result of $e n$ and $a$ 'dropping' and goes on to note that in Danish the 


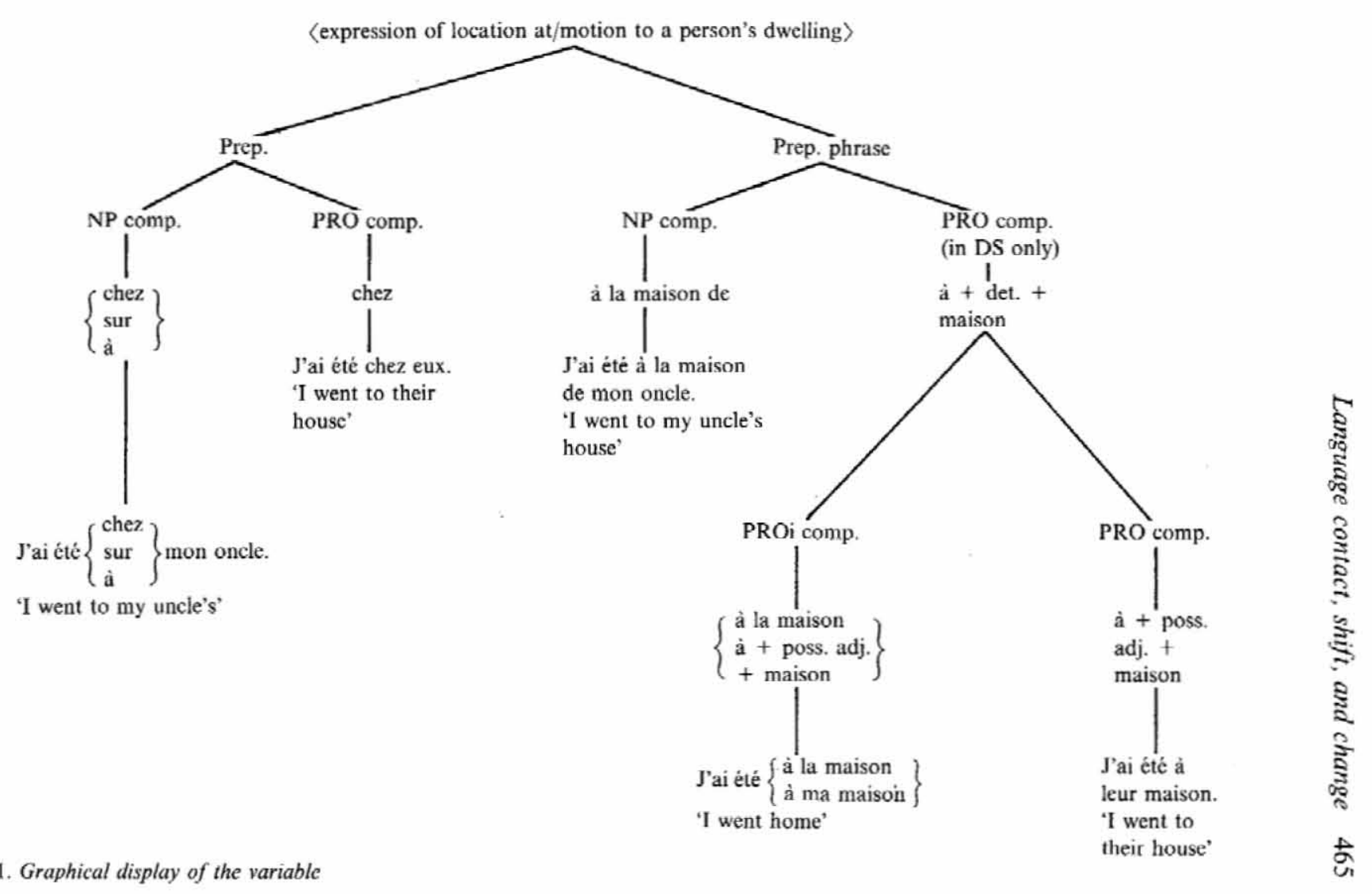

Figure 1. Graphical display of the variable 
preposition hos 'chez' must have extracted itself in the same way from prepositional phrases involving the noun hus 'house'. Nyrop's view of chez's formation is echoed by Bloch and Wartburg (1950: 123), who note a parallel development in Picard and Wallon where the preposition mon 'chez' is said to have formed out of prepositional phrases like $\dot{a}$ notre maison 'at our house'. Picard and Wallon are in fact dialects in which no trace of Latin casa remains (cf. Wartburg 1969: 248). It is instructive to consider what Wartburg had to write about the precise mechanism or stages of preposition mon's formation in Picard and Wallon:

In the extreme northern part of Roman Gaule, in Picardie-Wallonie, mansio was able to displace its oldest adversary casa even in its prepositional usage; the composed forms en meson, à meson, etc., gave birth to the prepositions èmon, amon, etc. These prepositions with $e n$ and $\dot{a}$ in turn gave rise to the elliptical form mon 'chez'. It is the proclitic use of the prepositions èmon and amon that explains the phonetic fusion [our translation and adaptation from the German original].

The question is whether this account is convincing. It seems to us a rather roundabout way to explain mon's formation and by extrapolation chies' (or ches'). Indeed, while the fusion or coalescence of the initial prepositions en and $a$ with the following nouns meson and chies (or ches) is a natural development, the dropping of the initial prepositions or their merging with the noun to the point of leaving absolutely no trace isn't. An alternative hypothesis is that chez or more precisely chies (or ches) is a direct descendent of the Vulgar Latin noun casa, used without a preposition to signal location at or motion to a person's dwelling. Though we lack information on Vulgar Latin, this view derives support from the fact that the Classical Latin noun domus 'house' (which casa replaced in Vulgar Latin) could be used in exactly this way (as in domum Pompenii venire 'to come to Pomponius' house') (cf. Gaffiot 1934: 555). Of course, the breakdown of the case system must have led quite early to the introduction of the prepositions in and ad before casa (cf. Bloch and Wartburg 1950: 123) and this is precisely what is reflected in the Old French forms en chies and a ches. But since maison had become the common word for 'house' in Old French, chies (or ches) could hardly still have had nominal status in en chies and a ches. Despite the spelling, en chies and a chies were probably already fused forms in Old French and in this respect it may be noted that Wartburg (1940: 451) and Toblers and Lommatzsch (1954: 203-204) cite the Old French preposition enchies represented graphemically as a single lexical unit. We may suppose that the fused form aches existed as well, especially since there are reflexes of it (for example, assi or assié) in certain dialects of France (cf. Wartburg 
1940: 450). We would contend, then, that instead of depicting chies (or ches) as having somehow extracted itself from the analytic forms en chies and $a$ ches (via an as yet unexplained dropping of the initial prepositions) or from the fused forms enchies and aches (via an as yet unexplained phonetic reduction of $e n$ and $a$ ), one should posit the coexistence of three prepositional options in Old French: chies (or ches), enchies, and aches. It turns out that chies (or ches) is the option which won out in French to give chez, but in other dialects it is the fused forms which survived (cf. the above-mentioned examples of assi and assié). In other dialects still, none of these prepositions survived if they were ever formed (cf. the abovementioned examples of Picard and Wallon). ${ }^{10}$

\subsection{Sur}

The preposition sur (<Latin super 'on, above'), used in the sense of 'chez', is attested by both Wartburg (1966: 432) and Littré (1968b: 595 ) in the late 14th or early 15th centuries (as in Je descendis à l'hostel de la Lune sur un escuyer du comte, lequel ... 'I stayed at the Hôtel de la Lune at a gentleman of the count's, who ...'). The same usage is attested again by Huguet (1967: 135) in the 16th century (as in Le bon chevalier ... la mena ... coucher sur une gentil-femme sa parente the good knight ... took her ... over to sleep at a gentlelady's, a relative of his'). Haase (1969: 351-353), however, does not report this usage in the next century. While this may be taken as an indication that sur meaning 'chez' had probably disappeared from the standard language in the 17th century, it must be hypothesized to have survived in some of the dialects and then been brought over to Canada by the French settlers. Indeed, sur 'chez' is attested in Québécois French at the turn of this century by La Société du Parler Français au Canada (1968: 647) and is reported again more recently by La Follette (1969: 152-153), Barbeau (1970: 263, 265), and Seutin (1975: 345-346).

It so happens, however, that there was another preposition, sus ( $<$ Latin sursum 'at the top, toward the top'), which is attested in the sense of 'chez' roughly at the same time as sur (cf. Wartburg 1966: 463). And we learn from Juneau (1972: 200) that there was already a strong tendency not to pronounce word-final $s \mathrm{~s}$ in 16th century French. This suggests that the weakening of word-final ss started much earlier (cf. Morin 1981: 35-47). Now we learn from Straka (1965: 591-594, reported in Juneau 1972: 164) that word-final $r$ s were also not pronounced between the 13th and 17th centuries. As a result of these two rules of final-consonant deletion, the prepositions sur and sus must have merged very early in the 
history of French. Hence it is not possible to tell whether the form we have attested in our speech corpus and transcribed as $s u(r)$, pronounced [sy], descends from sus (< Latin sursum) via final-s deletion, or whether it comes from sur (<Latin super) via final-r deletion. Juneau (1972: 170, note 36 ) opts for the former etymology, although he provides no convincing argument in support of his choice.

Aside from this etymological problem, what remains puzzling (and only serves to add to the etymological dilemma, as we will see) is how sur (and sus for that matter) managed to acquire the meaning of 'chez'. The reader will no doubt agree with us that this novel meaning appears far removed from the original meanings of sur 'on, above' and sus 'at the top, toward the top'. It is conceivable, therefore, that sur and sus did not acquire the meaning of 'chez' via a natural semantic evolution. An alternative explanation is the following. In many dialects of France the initial consonant of chies changed to [s] and its vowel to [y], wherein Bloch (1917: 116) sees an influence of the preposition sus; but Wartburg (1940: 452) cautions that the phonetic changes that chies underwent may have taken place naturally given the atonic position of the word. If Wartburg is correct, then it opens up the possibility that sur and sus acquired the meaning of 'chez' due to their homophony with $s u(<$ chies). We already know that chies is attested several centuries before either sur or sus acquired the additional meaning of 'chez'. This would have given chies more than enough time to undergo its presumed natural phonetic evolution to $s u$. Should this scenario prove accurate, it would mean that there is yet a third possible etymological source for synchronic $s u(r)$ 'chez' (i.e. <su < chies).

How, then, do our speakers of Ontarian French analyze $s u(r)$ ? As our orthographic transcription has intimated all along, there is reason to think that, synchronically speaking, $s u(r)$ must be analyzed as a phonetic variant of the full form sur. First of all, it will be remembered that sur occurred more often ( 5 tokens) than did $s u(r)$ ( 3 tokens) with the meaning of 'chez'. Thus if the two forms are to be related lexically, as we think, it follows that sur should be taken as the base form. Second, the rule of final- $r$ deletion may be seen to still be operant synchronically in linguistic contexts where sur has the primitive meaning of 'on, above' as illustrated in examples (5a) and (5b):

(5) a. Le sucre est $s u(r)$ la table.

'The sugar is on the table.'

b. Elle est tombée $s u(r)$ le genou.

'She fell on her knee.'

Given these two observations, the optimal grammar must be one in 
which $s u(r)$ 'chez' is also interpreted as an $r$-less pronunciation of sur. Of course, another possibility would be to claim that $s u(r)$ 'chez' is really a separate preposition and that our speakers are hypercorrecting by inserting a final $r$ on the analogy of sur $>s u(r)$ 'on, above'. But this is tantamount to saying that our speakers do indeed perceive a lexical relationship between sur and $s u(r)$ 'chez'. Whichever way one chooses to look at the problem, then, it appears that the simplest solution is to argue that $s u(r)$ is an $r$-less pronunciation of sur. We still maintain, however, that had we not had the benefit of historical information, we would probably never have considered the possibility that $s u(r)$ could be anything else but a phonetic variant of sur.

In light of the fact that the use of the preposition sur in the sense of 'chez' disappeared from the standard language in the 17th century, it will be interesting to see in the next section just how well this archaism has managed to survive in Ontarian French. As we will see, we should not be misled into thinking that it is on the brink of extinction just because we only found eight occurrences representing merely $3 \%$ of the total number of actualizations of the variable.

\section{3. $\dot{A}$}

The use of the preposition $\dot{a}$ in the sense of 'chez' most probably predates the emergence of the preposition chez itself since already in Classical Latin $a d>a ̀$ was used in this way (as in fuit ad me sane diu 'he stayed at my house a very long time') (cf. Gaffiot 1934: 28 ). Yet there is no explicit reference to any such use of the preposition $\dot{a}$ in the etymological dictionaries that we consulted. However, Toblers and Lommatzsch (1925: 3) do list, under the preposition $\grave{a}$, several Old French examples where $\dot{a}$ translates the meaning of 'chez' (for example, se hierbegoient as boines gens que il trovoient 'they stayed with the good people that they found'; hebergier en boine vile au plus haut oste, au plus nobile 'to stay in a good city with the highest host, with the noblest'). Still, it should probably be assumed that $\dot{a}$ was at best only occasionally used in the sense of 'chez' in Old French for this usage to have escaped the attention of historical linguists. Could it be that the creation of the preposition chez in Old French curtailed the need to maintain another preposition? It is interesting to note that in Occitan, a dialect in which chez is not attested, it is precisely the preposition $\grave{a}$ which is found instead (as in $\underline{a} M$. tal 'at Mr. so and so's') (cf. Piat 1970). In accord with the lack of explicit reference to $\dot{a}$ 'chez' in Old French, Huguet (1925: 1-4) does not report this usage in the 16th century nor does Haase (1969: 314) in the 17th century. This is also 
quite in keeping with the fact that none of the works on past or contemporary varieties of Canadian French that we consulted makes note of the use of $\dot{a}$ in the sense of 'chez'. By all appearances, the $\dot{a}$ we have attested in Ontarian French in the sense of 'at/to someone's home' is not an historical preservation like sur since it goes unattested after the Old French period. Though it could have survived UNNOTICED in certain dialects and made its way to Canada at the time of colonization, we will see in the next section that there is synchronic evidence that $a$ is indeed not an archaism but an innovation (admittedly resembling a previously attested usage in the history of French).

\section{4. À la maison and à la maison de}

The prepositional phrase à la maison does not seem to be attested until the 16th century, in other words several centuries after chez (cf. Wartburg 1969: 241). This is not to say, however, that from the 12th century (period of chez's first attestation) to the 16th there were no prepositional phrases with maison serving as alternatives to chez. Littré (1967: 1862) cites examples of à la maison de and en la maison de dating back to the 11th and 12th centuries (for example, Si le pere truvet sa file en avulterie en sa maison 'if the father found his daughter committing adultery in his house'). This is an indication that at the same time the old prepositional phrases en chies and a ches were becoming opaque due to the replacement of chiese (or chese) by maison and/or to the divergent phonetic evolution of chiese (or chese) in tonic vs. atonic position (cf. note 10), the language wasted no time in creating new transparent phrases around the noun maison. But why à la maison was apparently created some considerable time later than à la maison de is a question that we cannot answer at this moment. What little is known about the evolution of à la maison and à la maison de after the OHd French period (cf. Wartburg 1969: 241) seems to indicate that the only one of these two variants which survived beyond the Middle French period to the present day is à la maison. It would be interesting to find out whether the other variant fell by the wayside naturally or whether on the contrary the prescriptive grammarians intervened in some way or other. Assuming that à la maison de really does have a discontinuous history (i.e. did not linger on unnoticed in some dialects), then its presence in Ontarian French seems to be another instance of 'reemergence' of a previously attested usage, like the variant $a$. In the following section synchronic evidence will again be adduced in favor of the hypothesis that we are dealing with an innovation. 


\section{Synchrony of the variable}

Judging from the cases which have been reported in the literature, linguistic variation is usually binary (cf. Sankoff and Labov 1979: 194 for a similar impression). As a result, the statistical analysis of linguistic variation normally requires an ordinary two-variant variable-rule analysis (cf. Sankoff and Rousseau 1983). Sankoff and Rousseau have demonstrated that the statistical analysis of linguistic variables that are realized by more than two variants - what might be termed 'multivariables' poses the problem of token classification. However, Table 1 provides a general picture of the variants' distribution as a function of the linguistic

Table 1. Distribution of the variants by factor group

\begin{tabular}{|c|c|c|c|c|c|c|c|c|}
\hline \multirow{2}{*}{$\begin{array}{l}\text { Factor } \\
\text { groups }\end{array}$} & \multirow{2}{*}{$\begin{array}{l}\text { chez } \\
\mathrm{N}(\%)\end{array}$} & \multirow{2}{*}{\multicolumn{2}{|c|}{$\begin{array}{l}\text { sur } \\
\mathrm{N}(\%)\end{array}$}} & \multirow{2}{*}{\multicolumn{2}{|c|}{$\begin{array}{l}\grave{a} \\
\mathrm{~N}(\%)\end{array}$}} & \multirow{2}{*}{$\begin{array}{l}\text { àlamaison } \\
\mathrm{N}(\%)\end{array}$} & \multicolumn{2}{|c|}{ à la maison de total } \\
\hline & & & & & & & N $(\%)$ & N $(\%)$ \\
\hline \multicolumn{9}{|c|}{ Locality of residence } \\
\hline Hawkesbury & $40(83 \%)$ & 1 & $(2 \%)$ & 0 & $(0 \%)$ & $7(15 \%)$ & $0 \quad(0 \%)$ & $48(100 \%)$ \\
\hline Cornwall & $51(65 \%)$ & 5 & $(6 \%)$ & 1 & $(1 \%)$ & $17(22 \%)$ & $4(5 \%)$ & $78(100 \%)$ \\
\hline North Bay & $35(52 \%)$ & 2 & $(3 \%)$ & 3 & $(4 \%)$ & $25(37 \%)$ & $2(3 \%)$ & $67(100 \%)$ \\
\hline Pembroke & $40(61 \%)$ & 0 & $(0 \%)$ & 4 & $(6 \%)$ & $20(30 \%)$ & $2(3 \%)$ & $66(100 \%)$ \\
\hline \multicolumn{9}{|c|}{ Frequency of use of French } \\
\hline High & $69(77 \%)$ & 2 & $(2 \%)$ & 0 & $(0 \%)$ & $18(20 \%)$ & I $(1 \%)$ & $90(100 \%)$ \\
\hline Mid & $53(54 \%)$ & 6 & $(6 \%)$ & 3 & $(3 \%)$ & $33(34 \%)$ & $3(3 \%)$ & $98(100 \%)$ \\
\hline Low & $44(62 \%)$ & 0 & $(0 \%)$ & 5 & $(7 \%)$ & $18(25 \%)$ & $4(6 \%)$ & $71(100 \%)$ \\
\hline \multicolumn{9}{|l|}{ Social class } \\
\hline Middle & $29(71 \%)$ & 1 & $(2 \%)$ & 0 & $(0 \%)$ & $11(27 \%)$ & $0(0 \%)$ & $41(100 \%)$ \\
\hline Lower-middle & $71(59 \%)$ & 1 & $(1 \%)$ & 3 & $(2 \%)$ & $40(33 \%)$ & $6(5 \%)$ & $121(100 \%)$ \\
\hline Working & $66(68 \%)$ & 6 & $(6 \%)$ & 5 & $(5 \%)$ & $18(19 \%)$ & $2(2 \%)$ & $97(100 \%)$ \\
\hline \multicolumn{9}{|l|}{ Sex } \\
\hline Male & $74(61 \%)$ & 2 & $(2 \%)$ & 5 & $(4 \%)$ & $36(30 \%)$ & $5(4 \%)$ & $122(100 \%)$ \\
\hline Female & $92(67 \%)$ & 6 & $(4 \%)$ & 3 & $(2 \%)$ & $33(24 \%)$ & $3(2 \%)$ & $137(100 \%)$ \\
\hline \multicolumn{9}{|l|}{ Verb } \\
\hline Motion & $73(74 \%)$ & 6 & $(6 \%)$ & 5 & $(5 \%)$ & $11(11 \%)$ & $3(3 \%)$ & $98(100 \%)$ \\
\hline Static & $93(58 \%)$ & 2 & $(1 \%)$ & 3 & $(2 \%)$ & $58(36 \%)$ & $5(3 \%)$ & $161(100 \%)$ \\
\hline \multicolumn{9}{|l|}{ Complement } \\
\hline PROi & $126(64 \%)$ & 0 & $(0 \%)$ & 0 & $(0 \%)$ & $69(35 \%)$ & $3(1 \%)$ & $198(100 \%)$ \\
\hline PRO & $6(67 \%)$ & 0 & $(0 \%)$ & 0 & $(0 \%)$ & -- & $3(33 \%)$ & $9(100 \%)$ \\
\hline NP & $34(65 \%)$ & & $(15 \%)$ & & $(15 \%)$ & -- & $2(4 \%)$ & $52(100 \%)$ \\
\hline Total & $166(64 \%)$ & 8 & $(3 \%)$ & 8 & $(3 \%)$ & $69(27 \%)$ & $8(3 \%)$ & $259(100 \%)$ \\
\hline
\end{tabular}


and social factor groups under consideration, from which it can be seen that the only variants deserving of a more sophisticated statistical analysis are the standard options chez and à la maison, the other variants just being too infrequent. We will nevertheless discuss the infrequent variants' distribution especially as it sheds light on their synchronic status (i.e. archaism vs. innovation).

Among other things, the examination of the variants' synchronic social distribution will not only provide proof of $\dot{a}$ and $\dot{a}$ la maison de's status as innovations, it will also play up the existence of a tendency on the part of some speakers to overuse the variant $\dot{a}$ la maison. In attempting to account for these qualitative and quantitative developments, we will systematically adopt a contrastive vs. internal approach. By contrasting the English and French prepositional systems we will weigh the plausibility of interlingual transfer, yet remembering the axiom of historical linguistics that change proceeds first and foremost from system internal causes, we will give equal consideration to the possibility of an autonomous origin of these developments. By proceeding in this fashion, we will illustrate one of the pitfalls of language contact research, namely that developments which are claimed to be due to interlingual transfer are often just as easily explained intralingually as simplifications (cf. Muysken 1984: 53 who makes the same point).

\subsection{The main variants}

We performed a variable-rule analysis of the variation between $c h e z$ and $\dot{a}$ la maison in the context of a following PROi. To this end we disregarded the three occurrences of à la maison de (or more precisely its allophrase $\dot{a}$ + poss. adj. + maison) that occurred in the same context. The particular version of the variable-rule program we resorted to was VARBRUL $2 S$ (cf. Sankoff 1979). This program does a stepwise regression analysis, yielding an ordered selection of the factor groups (such as sex) which are significant predictors of variant choice. It also provides the effect of each one of the factors (such as male, female) on variant choice. The effects vary between 0 and 1 , favoring rule application (here use of chez) when greater than .5 , inhibiting it when less than .5. The results of the VARBRUL $2 \mathrm{~S}$ analysis of chez vs. $\dot{a}$ la maison appear in Table 2. Although not all of the factor groups have a bearing on the issue of primary concern to us (i.e. what are the effects of bilingualism and language restriction on linguistic structure?), we will consider them all the same because of their own particular interest. However, the germane factor groups will be considered first. 
Table 2. Results of variable-rule analysis of chez vs. à la maison

\begin{tabular}{lcccc}
\hline Factor groups & N of chez & Total & $\%$ chez & Effect \\
\hline Locality & & & & \\
Hawkesbury & 36 & 43 & $84 \%$ & .745 \\
Cornwall & 37 & 54 & $69 \%$ & .532 \\
Pembroke & 29 & 49 & $59 \%$ & .366 \\
North Bay & 24 & 49 & $49 \%$ & .342 \\
Frequency of use of French & 56 & & & \\
High & 42 & 74 & $76 \%$ & not \\
Mid & 28 & 46 & $56 \%$ & sign. \\
Low & & & $61 \%$ & \\
Social class & 22 & 33 & $67 \%$ & not \\
Middle & 55 & 94 & $59 \%$ & sign. \\
Lower-middle & 49 & 68 & $72 \%$ & \\
Working & & & & \\
Sex & 56 & 93 & $60 \%$ & not \\
Male & 70 & 102 & $69 \%$ & sign. \\
Female & & & & .669 \\
Verb & 50 & 61 & $82 \%$ & input $=.735$ \\
Motion & 76 & 134 & $57 \%$ & \\
Static & 126 & & $65 \%$ & \\
Total & & & & \\
\hline
\end{tabular}

5.1.1. Locality of residence. Table 2 reveals that the speakers residing in the predominantly francophone locality of Hawkesbury show a much higher propensity to use chez (.745) than the speakers residing in the minority francophone localities of Cornwall (.532), Pembroke (.366), and North Bay (.342). One interpretation of these results is suggested by contrasting the English and French prepositional systems. The variant $\dot{a}$ la maison corresponds to the English equivalent structure (at) home and therefore one might suppose that those among our speakers who know English well (i.e. the minority locality speakers) identify à la maison with (at) home, resulting in a tendency on their part to overuse this variant at the expense of $c h e z+P R O i$, a construction which has no similar English equivalent. This interlingual identification and resultant convergence would be to the bilingual, as Weinreich (1968: 8) aptly put it, 'a reduction of his linguistic burden'. It needs to be recognized, however, that the minority locality speakers' proclivity to use à la maison only constitutes 
necessary, not sufficient empirical evidence in support of the convergence hypothesis. The hypothesis must be taken one step further in order to see whether there are any plausible internal explanations for the minority locality speakers' greater inclination toward à la maison. Beforehand, however, it will be helpful to consider the results pertaining to the factor group 'frequency of use of French'.

5.1.2. Frequency of use of French. Frequency of use of French was not selected as a significant predictor of variant choice despite what would appear to be a substantially higher frequency of use of chez by the speakers who reported a high level of use of French $(76 \%)$ than by the mid- and low-frequency users of French ( $56 \%$ and $61 \%$ respectively). This is, it turns out, because locality of residence is a confounding factor group when it comes to assessing the effect of frequency of use of French. The Hawkesbury speakers, all of whom reported a high frequency of use of French, used chez $84 \%$ of the time. It is this very high percentage that elevates the frequency of use of chez by the high-level users of French as a whole (i.e. irrespective of their locality of residence) to $76 \%$. If we were to disregard the Hawkesbury speakers' occurrences of the variable, the percentage of use of chez by the minority locality speakers who have a high level of use of French (i.e. $20 / 31=65 \%$ chez) would no longer be very different from the percentages that obtain for the speakers who display only mid or low levels of use of French. ${ }^{11}$

The reader will recall that our original motivation for controlling frequency of use of French was not only the expectation that restricted users of this language would experience influence from English, but that they would also simplify the language (where it presents less their optimal structure, as in irregularities, infrequent forms, etc.). For example, we discovered a significant tendency on the part of the low- and midfrequency users of French to level the $3 \mathrm{pl}$. forms of verbs via an overgeneralization of the unmarked 3sg. forms, e.g. ils savent 'they know' $>$ ils sait 'they knows'; elles veulent 'they want' > elles veut 'they wants'; etc. (Mougeon and Beniak 1981). Returning to the case at hand, could the minority locality speakers' greater inclination toward à la maison not also be the result of a move toward simpler structure? There are certainly grounds to argue that à la maison is more transparent than chez + PROi. For one, $\dot{a}$ is the general locative and directional preposition in French; also, maison denotes the notion of 'dwelling'. In contrast, chez is a highly specialized preposition of location and direction, not to mention that its pronominal complement obviously does not designate a person's home. Assuming for the sake of argument that there is a difference in semantic transparency, then all else being equal, in cases of restricted exposure to 
and use of French one might expect the bilingual's speech to show a higher than normal frequency of use of à la maison in comparison to the less transparent chez + PROi. Our assumption is analogous to Andersen's (1982: 99) hypothesis regarding syntactic reduction in the speech of learners undergoing language attrition (LAs): 'The LA will preserve and overuse syntactic constructions that more transparently reflect the underlying semantic and syntactic relations.' This internal scenario, however, is in contradiction with the fact that the low- and mid-level users of French (i.e. those who have been shown in previous research of ours to speak a simplified form of French) were not found to overuse $\dot{a}$ la maison in comparison to the high-level users of French residing in the minority francophone localities. If all of the minority locality speakers, irrespective of their level of retention of French, overuse à la maison in comparison to the majority locality speakers, then it seems obvious that more or less restricted use of French cannot be the sociological stimulus. This may be due to the fact that, in reality, not all else is equal between the two prepositional variants. Chez enjoys a much wider linguistic distribution (cf. section 3) and is much more frequent in the specific context of PROi (almost twice as frequent, in fact, judging by the results in Table 1). Thus it would seem that Andersen's prediction regarding the overuse of transparent constructions as a result of language restriction (or 'attrition' in his terminology) may not hold in the situation where the alternative construction possesses properties which militate in favor of its maintenance.

In sum, in light of the quantitative sociolinguistic evidence of a greater tendency to use à la maison, the English-like variant, in localities where contact with English is INTENSIVE (i.e. where there are many bilingual Francophones) and considering the implausibility of ascribing this crosslinguistic rapprochement to internal factors, the conclusion seems warranted that convergence is responsible. ${ }^{12}$

5.1.3. Sex and social class. Not only is linguistic variation usually binary but one of the variants usually corresponds to standard usage while the other doesn't (cf. Thibault 1983: 55 for a similar opinion). The two variants are thus expected to show an uneven distribution between the two sexes and across the social classes or a related measure such as degree of insertion in the linguistic market (cf. Sankoff and Laberge 1978). However, since the two principal variants chez and à la maison correspond to standard usage, one would on the contrary expect them to be EVENLY distributed across the social classes and between the two sexes. As indicated by the results in Table 2 , the variable-rule analysis confirmed this hypothesis since neither sex nor social class was selected as a 
significant predictor of choice of chez vs. à la maison. So contrary to what Bourdieu (1982: 20) has written, there do seem to be words that are 'neutral' if we interpret neutral to mean 'spread equally throughout the various social classes and the two sexes.' As Table 2 reveals, however, this does not mean that each variant is used half of the time. All the social classes and both sexes show a distinct preference for chez over à la maison. Chez's wider linguistic distribution (cf. section 3) may be the reason.

5.1.4. Verb. Selection of chez vs. à la maison turned out to be predicted best by a feature of the linguistic context, namely the type of verb (i.e. motion vs. static) with which these variants cooccurred. Table 2 shows that chez cooccurred with a motion verb significantly more often than did à la maison (.669 vs. .331). This is the sort of weaker constraint or tendency we said we might find when examining the data quantitatively. ${ }^{13}$

\subsection{The secondary variants}

Let us now return to Table 1 in order to discuss the less frequent variants' distribution. Because no statistical tests were performed we will selectively discuss only those factor group results which have a bearing on the question of the archaic vs. innovative status of the infrequent variants.

5.2.1. Sur. Sur's concentration in working-class speech is consonant with its nonstandard status. Furthermore, its absence in the speech of the low-level users of French is reminiscent of the similar fate of another nonstandard prepositional usage we studied (cf. Beniak and Mougeon 1984). The particular kind of domain restriction in language use experienced by the low-frequency users of French (the school is their primary source of exposure to and use of French; cf. section 2 and note 4) obviously has a negative impact on their ability to acquire certain features of the vernacular which depart from the standard norm. In contrast, in bilingual communities where schooling in the minority language is not available, what has been reported instead is a failure to acquire (or more exactly to appropriately use) certain features which are typical of the standard language. For instance, in a Hungarian-speaking enclave in Austria, Gal (forthcoming) observed a narrowing of the phonological style of young bilinguals whose use of Hungarian was confined to the home. The older speakers, who still used Hungarian for a broad range of social functions, knew how to adapt their phonological style according to the level of formality of the speech situation. King (1984) reports very much the same kind of stylistic reduction at the lexical level in four 
French-speaking communities in Newfoundland, Canada. The above suggests that it is not so much general disuse of the minority language as its disuse in specific contexts which results in a reduction of the bilingual's stylistic repertoire, a distinction we did not foresee when we undertook our sociolinguistic research (cf. section 2).

Interestingly, the same infrequent users of French at times give the impression of having acquired nonstandard traits of the vernacular. Upon closer scrutiny, however, it is always the case that the nonstandard variants in question can be produced independently via simplification and/or influence from English. ${ }^{14}$ From the fact that sur was not used at all by the low-frequency users of French we can deduce that there is no internal and/or external process underlying the use of this variant and hence that it relies solely on intergenerational transmission for its survival. The question then arises as to how well (or poorly) it is faring. In order to answer this question we must limit ourselves to the context of a following nominal complement since this is the only context which seems to allow sur. In so doing sur's frequency jumps from $3 \%$ overall to $15 \%$. In other words, the variable is actualized as sur $15 \%$ of the time when the following complement is a noun. But in order to gain an even more accurate measure of sur's vitality we should also restrict ourselves to working-class speech since this is the sociolect in which sur is mainly concentrated. When this is done, its frequency reaches $22 \% .{ }^{15}$

5.2.2. $\grave{A}$. Does Table 1 also enable us to be more definite about $\grave{a}$ 's synchronic status if we look at this variant's distribution? It will be recalled that $\ddot{a}$ 's discontinuous history suggested it was not a preservation of an analogous usage previously attested in Old French but an innovation of Ontarian French. Were $\dot{a}$ an archaism, its distribution as a function of level of use of French should resemble sur's, but what we observe instead is almost the opposite distribution: the speakers who make the most frequent use of French never use $\dot{a}$ while those with the most restricted use of French use $\dot{a}$ the most. Such a distribution suggests strongly that the variant $\dot{a}$ cannot be a typical trait of the vernacular, otherwise it would have been handed down first and foremost to the speakers who have a high level of use of French. It has to be the case, then, that the low- and mid-level users of French 'got' $a$ in some way other than via exposure to it. The contrastive approach again offers one possible explanation, namely that $\grave{a}$ is the result of interference from English, a language that all of the low- and mid-level users of French know well and by definition use actively. English uses the prepositions at or $t o$, the equivalents of French $a$, to express the notion of location at/motion to a person's home (cf. glosses of examples in section 3). The 
interference hypothesis is plausible to the extent that anglophone second language learners of French have been observed to have the same feature in their interlanguage (cf. Spilka 1976). A counterexplanation, however, is that the variant $a$ is due to incomplete learning of the rule restricting the use of the general locative and directional preposition $a$ to inanimate nouns referring to places. This internal simplification hypothesis is also plausible in view of the fact that young Francophones learning their mother tongue overgeneralize $\dot{a}$ in precisely this way (based on the first author's informal observation of his children's linguistic development). We are confronted once again (cf. note 14) with a structural development admitting competing inter- and intralingual explanations.

The social class results reveal that $\dot{a}$ is an innovation of the lowermiddle and especially the working class. This ties in with the oft-made observation that popular varieties of language show the most advanced stages of evolution (cf. Lefebvre's 1982 collection of studies on popular Montreal French and Frei's 1971 and Guiraud's 1973 works on popular European French). In fact Frei (1971: 150) provides a number of substitutions of $\grave{a}$ for other prepositions, including chez (as in M.M. attendait les visiteurs pour les conduire à la mère de l'aviateur 'M.M. was waiting for the visitors in order to bring them to the aviator's mother'). This constitutes further evidence that the preposition $a$ may autonomously develop the meaning of 'chez' in the absence of contact with English or restriction in language use. For all of its internal motivation, however, this variant's development in Ontarian French seems precisely to have taken place only where lower-class background intersects with knowledge of English and/or restriction in the use of French.

5.2.3. À la maison de. À la maison de (and its allophrase $\grave{a}+$ poss. adj. + maison) is another variant whose interrupted history suggested it was an innovation of Ontarian French as opposed to a surviving usage first attested in Old French. This suggestion is further supported by the results in Table 1 to the extent that the variant's distribution according to social class and frequency of use of French is quite similar to $a$ 's. The same two types of explanations that were proposed in the case of $\grave{a}$ can be offered here as well. On the one hand it is possible that à la maison de is the product of the influence of the corresponding English construction at/to someone's house (cf. glosses of examples in section 3). In this connection the second author has informally observed examples of $a$ la maison de in the spoken French of anglophone early-immersion students in Montreal. On the other hand it is possible that $a$ la maison de is a natural analogical extension of the standard and frequent variant $\dot{a}$ la maison to contexts involving nominal complements and pronominal complements whose 
antecedent lies outside the sentence or which do not refer to the speaker (i.e. PRO). In support of the latter explanation we can once again rely on the first author's informal observation of numerous tokens of à la maison de (also dans la maison de) in the spoken French of his two young monolingual children. So there is ambiguity surrounding the exact cause of this innovation, just as there was in the case of $\dot{a}$.

\section{Discussion}

Through the multiplicity and diversity of its variants, the variable examined in this paper 'encapsulates' as it were three distinct consequences of bilingualism, and accompanying language shift, on linguistic structure. Bilingualism impacts on linguistic structure through interlingual influence, which famous scholars such as Weinreich (1968) and Haugen (1969) have claimed to be an inevitable byproduct of language contact. In this regard, it was found that there is a tendency for Ontarian French to converge with English in localities where Francophones are outnumbered by Anglophones. Convergence is a subtle effect of language contact that can only be isolated through quantitative investigation since it does not entail any qualitative deviation from the conservative norm represented by the speech of the high-frequency users of the minority language, only a statistical one (cf. Silva-Corvalán 1983).

In retrospect, however, it seems we need to qualify our original equation between the speech of the high-frequency users of French and the conservative norm. In localities where Franco-Ontarians form only a minority of the population, there is in fact no guarantee that the speech of those who retain French at a high level will be a valid base line for gauging the speech of those who do not maintain the minority language to the same degree. The problem is that the same developments that are observable in the speech of the latter might well also be observable in the speech of the former. When this is the case, it becomes necessary to have a control group of even higher retainers of French, i.e. ones residing in a locality where Francophones are in the majority. Thus it appears that minority language disuse need not be very pronounced before certain linguistic consequences begin to manifest themselves (here convergence). In fact, one may rightly wonder whether language restriction per se plays a part at all in the observed case of convergence. Knowledge of English (i.e. bilingualism) on its own seems to be sufficient as was argued above. Thus the issue at stake is, Does a bilingual's proficiency in that one of his two languages which is in a subordinate position sociologically have to become weakened through disuse before his other (i.e. the superordinate) 
language can begin to exert interlingual influence? The linguistic behavior of the high-level users of French residing in the minority francophone localities suggests that the answer is no. This is not to say, however, that other linguistic consequences do not require relative to pronounced disuse of the minority language in order to evidence themselves as we saw earlier and will have occasion to return to shortly.

A more salient manifestation of interlingual influence is interference, which differs from convergence in that it produces a new usage or qualitative change in the minority language. Despite their differences, interference and convergence are really two manifestations of the same underlying process of reduction or leveling of structural dissimilarities between languages in contact. In this connection, we saw that two innovative variants of chez (i.e. $\grave{a}$ and $\dot{a}$ la maison de) were arguably possibly due to interference from English. Alternatively, it seemed just as plausible to view $\grave{a}$ and $\grave{a}$ la maison de as simplifications due to relative to severe restriction in French language use. Interestingly enough, both were once used in the early stages of the language's history. Though for want of disambiguating data we were compelled to remain inconclusive concerning these variants' true structural origins (interlingual and/or intralingual?), it must be pointed out that we have had occasion to study other innovations characteristic of the speech of the less-frequent users of French which could only be attributed to influence from English (cf. for example Beniak et al. 1981) and others which could only be interpreted as simplifications (such as the previously mentioned instance of morphological simplification in the verb system; cf. Mougeon and Beniak 1981). Simplification of linguistic form is reported in all of the bilingual settings involving language shift that we know of and underlines the accuracy of Andersen's (1982: 91) assumption that

When a person's use of a language diminishes in such a way as to cause a break in that person's participation in the linguistic tradition that he previously had full participation in [if he ever had full participation in it], he is thus removed from the type and quantity of linguistic input and linguistic interaction necessary to maintain the full lexical, phonological, morphological, and syntactic distinctions that are made by fluent speakers of this language [our addition].

The ability to adapt the style of one's language to the level of formality of the speech situation is another aspect of the competence of fluent speakers that poses problems for speakers experiencing language restriction. Gal (forthcoming) played up an inability to switch from informal to formal phonological variants on the part of young Hungarian speakers who were bilingual in German and whose use of Hungarian was limited to 
the informal context of the home. Somewhat differently, we played up a failure to acquire informal prepositional usages on the part of speakers whose use of French was restricted to the school, where presumably the standard variety predominates. Andersen's assumption could easily be expanded to encompass stylistic distinctions as well. However, it was discovered that stylistic reduction is rather tied to language disuse in specific contexts (what others have called restriction in language function), whereas grammatical simplification is tied to general restriction in language use.

We would like to end the discussion on an issue which the findings of this study seem to have raised: the question of the structural integrity of minority languages. The present findings as well as previous ones of ours suggest that not even a high level of retention of French in Ontario (i.e. French-dominant bilingualism) is a safeguard against grammatical influence from English, any more than use of French on an equal footing with English is a guarantee against simplification. ${ }^{16}$ In contrast, Poplack's (1981) results seemed to suggest that as long as Spanish is spoken as often as English (i.e. balanced bilingualism) by New York's Puerto-Rican community, its grammar will not be adversely affected by influence from English nor, we may suspect, by simplification. Perhaps most forcefully in Poplack (1984), an attempt is made at demonstrating that SpanishEnglish bilingualism in New York City is stable even if English language use is advancing among the young Puerto-Ricans. There is no question, on the other hand, that French-English bilingualism is unstable in all except one of the Franco-Ontarian communities examined here. (In fact there is some doubt as to whether we can speak of the exceptional FrancoOntarian community as being bilingual.) We would then tentatively advance that it is perhaps only in a situation of UNSTABLE bilingualism that the structure of a minority language becomes prone to grammatical influence and simplification despite being used more often than or as often as the superordinate language by individual bilingual speakers. One difference between the two types of bilingualism is that when unstable bilingualism obtains, mid-level use of the minority language or balanced bilingualism may be merely a transitory stage toward shift to the majority language for some speakers. They might therefore be less motivated to preserve the integrity of their mother tongue. Another important difference is that in situations of unstable bilingualism speakers who are frequent users of the minority language or dominant in it are very often outnumbered by balanced bilinguals and majority-language-dominant bilinguals. This is the case among the adolescent generation in each one of the three minority communities we investigated. It is possible that in these French-speaking communities some of the innovations (whether transfer- 
induced or not) which arise in the speech of the balanced and Englishdominant bilinguals spread to the speech of the French-dominant bilinguals (cf. Haugen 1969: 370-371 on the notion of extent and direction of linguistic pressure within minority language communities).

Received 27 March 1985

Revised version received

26 July 1985

\author{
Centre for Franco-Ontarian Studies \\ Ontario Institute for Studies in Education \\ 252 Bloor Street West \\ Toronto, Ontario \\ Canada MSS 1 V6
}

\section{Notes}

* The research reported in this article was funded by a grant of the Social Sciences and Humanities Research Council of Canada, whose support we gratefully acknowledge. Thanks are also due to Johanne Thibault-Dalkian, who helped gather some of the information presented in the historical section, and to an anonymous reader and Nancy C. Dorian, both of whose comments allowed us to improve the content and the style of this paper. This is a considerably expanded version of a paper first presented at NWAVE IX, Ann Arbor, Oct. 30-Nov. 1, 1980.

1. As Dorian has rightly pointed out to us, 'Often enough a historical perspective isn't even available for use in the study of synchronic variation; the number of languages well and long enough studied to provide that kind of perspective is too small relative to the number of languages showing synchronic variation today.' Though in agreement with her statement, we would still maintain that the investigation of synchronic variation, even in languages whose history has been well studied (such as the Romance languages), is often not approached from an historical perspective.

2. Ontario's francophone population is the product of the immigration of various groups of Francophones from other Canadian provinces as well as from outside Canada, among which Quebeckers have been by far the major contributors (cf. Vallières 1980). The reasons which pushed these Frenchmen westward were essentially socioeconomic, i.e. the promise of new land to farm and new jobs in the forestry industry especially. (For an historical sketch of the French-Canadian migration westward in the 19th and early 20th centuries, cf. Vallières 1980: 59-159 and Choquette 1980.)

3. There are two reasons - very different in kind - why Ontario's French-language schools cater to such students. One is in the hope of 'refrancizing' them. The other is . that in some localities there simply are not enough fluent French-speaking students to viably support a French-language school. As a matter of survival, then, the school is more or less forced to open its doors to students of lesser fluency in French. This 'open arms' policy is not without creating attendant pedagogical problems, not the least of which is the existence of extremely heterogeneous classes in terms of French language proficiency. Some Franco-Ontarian teachers even go so far as to assert that the students of lesser fluency in French have a retarding effect on the linguistic and scholastic achievement of the more fluent speakers of French (cf. Mougeon et al. 1984).

4. The fact that schooling in the mother tongue is available to the Franco-Ontarian minority probably sets it apart from most of the other linguistic minorities which have 
been the object of sociolinguistic investigation, such as the Gaelic-speaking community of East Sutherland, Scotland (cf. Dorian 1981), or the German-speaking community of Gressoney in the Alps of Northern Italy (cf. Giacolone Ramat 1979), both of which are linguistic minorities whose language is not supported by the school system. But as linguistic minority groups continue their fight for the recognition of their right to education in their language, it is foreseeable that the Franco-Ontarian example will become more common. We will see that the speakers whose primary locus of exposure to and use of French is the French-language school experience a unique kind of domain restriction in language use having interesting consequences as far as lexical style is concerned.

5. The population statistics are taken from the 1981 Canada census.

6. It goes without saying that there are other types of location and direction besides simply being at or going to a person's home. Thus we also found expressions of direction away from or location other than at a person's dwelling (for example, $j$ 'parti vendredi soir de chez moi 'I left my house Friday night'; $y$ a une madame qui reste près de chez eux 'there's a lady who lives close to their house'; $j$ 'reste proche de votre maison 'I live close to your house'; ... des affaires qui arrivent alentour de la maison '... things that go on around the house'). We decided against extending the scope of the variable to include these other examples because of the unmanageable complexity this would have created, not to mention that it is not clear whether such an extension is legitimate in the first place.

7. Among the eight occurrences of sur, three were pronounced without the final $r$ as indicated via its enclosure in parentheses. We will have more to say about this when we consider sur from an historical perspective.

8. In contrast, there is frequent mention of the use of $a$ instead of chez in the related sense of 'at/to someone's place of work' (as in aller au docteur 'to go to the doctor') both in popular Canadian French (cf. La Société du Parler Français au Canada 1968: 1; Dionne 1974: 1) and in popular European French (cf. Bauche 1946: 123; Frei 1971: 150; Guiraud 1973: 73). It is a very old usage according to Grevisse (1975: 978). There are many examples in our own corpus.

9. Our failure to come across any occurrence of $\dot{a}$ la maison de in the context of a motion verb is surely an artifact of its very low frequency of occurrence (only 2 tokens in the entire corpus).

10. A question to consider is why mansio did not take casa's place as a preposition as well. We know that in Picard and Wallon mansio took over both functions. The answer might be that the tonic nominal forms chiese (or ches) grew to be phonetically distant enough that speakers no longer perceived them as related to each other. In effect this would have curtailed the replacement of chiese (or chese) by mansio from generalizing to the prepositional context.

11. That locality of residence is a confounding factor group is also mathematically illustrated by the various steps of the regression analysis. When level of use of French was considered by itself in the first step of the regression analysis, it was found to be significant at the .05 level. Even at the next step, when it was considered in combination with the previously selected factor group (i.e. verb), it still contributed significantly to explaining variant selection $(p<.05)$, but locality of residence was chosen instead because of its higher level of significance $(p<.01)$. But then when level of use of French was considered jointly with the two previously selected factor groups (i.e. verb and locality), it no longer contributed significantly to predicting variant choice $(p<.80$ only).

12. It would be interesting to try to ascertain whether the variation between $c h e z$ and $a$ la 
maison is stable or moving in the direction of greater use of one of the variants to the detriment of the other. If the convergence hypothesis is correct as we think, then Ontarian French should be evolving toward ever increasing use of à la maison in localities where Francophones are a minority (i.e. where bilingualism is likely to become even more widespread) but may be stable or evolving in the opposite direction where they are a strong majority. A cross-dialectal comparison with Québécois French could prove illuminating in this regard since one would expect Québécois and Hawkesbury French to evolve in tandem.

13. At the moment we are without an explanation for this finding.

14. For example, the use of the auxiliary avoir in place of être (as in j'ai parti en France 'I left for France') is a typical trait of Ontarian French which the low maintainers of the language also share despite their restricted exposure to the vernacular (cf. Canale et al. 1978). Child language acquisition research (cf. Grégoire 1947) has shown that French children whose parents do not substitute avoir for être overgeneralize avoir all the same. This inclines one to think that the presence of avoir as a variant of être in the speech of the low-level users of French is the outcome of the same overgeneralization (itself triggered by their restricted use of French) rather than an imitation of a usage already ingrained in the local vernacular (cf. Mougeon et al. 1984). On the other hand, second language learning research in the Canadian context (cf. Harley 1984) has shown that English-speaking learners of French also substitute avoir for être in spite of not being exposed to any variety of French but the standard at school. Since English has only one auxiliary for the formation of the compound tenses (i.e. have, the counterpart of avoir) whereas French has a binary system, the possibility of influence from English cannot be ruled out.

15. This percentage cannot be calculated directly from Table 1 since it is based on a crosstabulation of working class and NP complement. The crosstabulated results were $\mathrm{N}$ of sur $=6$; total $\mathrm{N}=27 ; \%$ sur $=22$.

16. We oppose grammatical influence to lexical influence or borrowing. We would claim that prepositions belong to the grammatical component of language because of their relational function and thus that we have attested English grammatical influence on Ontarian French.

\section{References}

Andersen, Roger W. (1982). Determining the linguistic attributes of language attrition. In Richard D. Lambert and Barbara F. Freed (eds.), The Loss of Language Skills, 83-118. Rowley, Mass.: Newbury House.

Barbeau, Victor (1970). Le français du Canada. Quebec City: Librairie Garneau.

Bauche, Henri (1946). Le langage populaire. Paris: Payot.

Bélisle, Louis-A. (1947). Dictionnaire générale de la langue française au Canada. Montreal: Librairie Beauchemin Limitée.

Beniak, Édouard, and Mougeon, Raymond (1984). Possessive $\dot{a}$ and $d e$ in informal Ontarian French: a long-standing case of linguistic variation. In Philip Baldi (ed.), Papers from the XIIth Linguistic Symposium on Romance Languages, 15-36. Amsterdam: Benjamins.

-, Mougeon, Raymond, and Valois, Daniel (1981). The problem of ambiguous change in a contact language. Paper presented at NWAVE X, Philadelphia, Oct. 23-25.

-, Mougeon, Raymond, and Valois, Daniel (1984/1985). Sociolinguistic evidence of a possible case of syntactic convergence in Ontarian French. Journal of the Atlantic Provinces Linguistic Association 6/7, 73-88. 
Bloch, Oscar (1917). Les parlers des Vosges méridionales. Paris: Librairie Ancienne M. Champion.

—, and Wartburg, Walther von (1950). Dictionnaire étymologique de la langue française. Paris: Presses Universitaires de France.

Bourdieu, Pierre (1982). Ce que parler veut dire. Paris: Fayard.

Canale, Michael, Mougeon, Raymond, and Beniak, Édouard (1978). Acquisition of some grammatical elements in English and French by monolingual and bilingual Canadian students. The Canadian Modern Language Review 34, 505-536.

Choquette, Robert (1980). L'Ontario français, historique. Montreal: Éditions Études Vivantes.

Dionne, Narcisse-E. (1974). Le parler populaire des Canadiens français. Quebcc City: University of Laval Press.

Dorian, Nancy C. (1977). The problem of the semi-speaker in language death. International Journal of the Sociology of Language 12, 23-32.

-(1981). Language Death. Philadelphia: University of Pennsylvania Press.

- (n.d.). Gathering language data in terminal speech communities. Unpublished manuscript.

Frei, Henri (1971). La grammaire des fautes. Geneva: Slatkine Reprints.

Gaffiot, Félix (1934). Dictionnaire illustré latin français. Paris: Librairie Hachette.

Gal, Susan (1979). Language Shift. New York: Academic Press.

- (forthcoming). Phonological style in bilingualism: the interaction of structure and use. In D. Schiffrin (ed.), Meaning, Form and Use in Context. Washington, D.C.: Georgetown University Press.

Giacalone Ramat, Anna (1979). Language function and language change in minority languages. Journal of Italian Linguistics 4, 141-162.

Grégoire, Antoine (1947). L'apprentissage du language, vol. 2. Paris: Société d'édition 'Les Belles Lettres'.

Greimas, A. (1968). Dictionnaire de l'ancien français. Paris: Larousse.

Grevisse, Maurice (1975) Le bon usage. Gembloux: Duculot.

Guiraud, Pierre (1973). Le français populaire. Paris: Presses Universitaires de France.

Gumperz, John J., and Wilson, Robert (1971). Convergence and creolization: a case from the Indo-Aryan/Dravidian border. In Dell Hymes (ed.), Pidginization and Creolization of Languages, 151-167. Cambridge: Cambridge University Press.

Haase, A. (1969). Syntaxe française du XVIIe siècle. Paris: Librairie Delagrave.

Harley, Birgit (1984). Age in Second Language Acquisition. Clevedon, England: Multilingual Matters.

Haugen, Einar (1969). The Norwegian Language in America. Bloomington, Ind.: Indiana University Press.

- (1977). Norm and deviation in bilingual communities. In P. A. Hornby (ed.), Bilingualism: Psychological, Social, and Educational Implications, 91-102. New York: Academic Press.

Huguet, Edmond (1925). Dictionnaire de la langue française du seizième siècle, vol. 1. Paris: Librairie Ancienne E. Champion.

- (1967). Dictionnaire de la langue française du seizième siècle, vol. 7. Paris: Didier.

Juneau, Marcel (1972). Contribution à l'histoire de la prononciation française au Québec. Quebec City: University of Laval Press.

Karttunen, Frances (1977). Finnish in America: a case study in monogenerational language change. In Ben G. Blount and Mary Sanches (eds.), Sociocultural Dimensions of Language Change, 173-184. New York: Academic Press.

King, Ruth (1984). Linguistic variation and language contact: a study of the French spoken in four Newfoundland communities. Paper presented at the 5th International Conference on Methods in Dialectology, Victoria, B.C., July 15-20. 
Kiparsky, Paul (1980). Concluding statement. In Elizabeth C. Traugott et al. (eds.), Papers from the 4th International Conference on Historical Linguistics, 409-417. Amsterdam: Benjamins.

Labov, William (1972). Sociolinguistic Patterns. Philadelphia: University of Pennsylvania Press.

-(1981). What can be learned about change in progress from synchronic description? In David Sankoff and Henrietta Cedergren (eds.), Variation Omnibus, 177-200. Edmonton: Linguistic Research.

La Follette, James (1969). Étude linguistique de quatre contes folkloriques du Canada français. Quebec City: University of Laval Press.

Larousse, Pierre (1966). Dictionnaire du français contemporain. Paris: Librairie Larousse.

La Société du Parler Français au Canada (1968). Glossaire du parler français au Canada. Quebec City: University of Laval Press.

Lefebvre, Claire (ed.) (1982). La syntaxe comparée du français standard et populaire: Approches formelle et fonctionnelle. Quebec City: Office de la languc française.

Littré, Émile (1967). Dictionnaire de la langue française, vol. 4. Paris: Gallimard/Hachette.

- (1968a). Dictionnaire de la langue française, vol. 2. Paris: Gallimard/Hachette.

- (1968b). Dictionnaire de la langue française, vol. 7. Paris: Gallimard/Hachette.

Morin, Yves-Charles (1981). Où sont passés les s finals de l'ancien français? In David Sankoff and Henrietta Cedergren (eds.), Variation Omnibus, 35-48. Edmonton: Linguistic Rescarch.

Mougeon, Raymond, and Beniak, Édouard (1981). Leveling of the 3sg./pl. verb distinctions in Ontarian French. In James P. Lantolf and Gregory B. Stone (eds.), Current Research in Romance Languages, 126-144. Bloomington, Ind.: Indiana University Linguistics Club.

-, Beniak, Édouard, and Côté, Normand (1981). Variation géographique en français ontarien: Rôle du maintien de la langue maternelle. Journal of the Atlantic Provinces Linguistic Association 3, 64-82.

_, Brent-Palmer, Cora, Bélanger, Monique, and Cichocki, Walter (1982). Le français parlé en situation minoritaire, vol. 1. Quebec City: International Center for Research on Bilingualism.

-, Heller, Monica, Beniak, Édouard, and Canale, Michael (1984). Acquisition et enseignement du français en situation minoritaire: Le cas des Franco-ontariens. The Canadian Modern Language Review 41, 315-335.

Muysken, Pieter (1984). Linguistic dimensions of language contact: the state of the art in interlinguistics. Revue québécoise de linguistique 14, 49-76.

Nyrop, Kr. (1899). Grammaire historique de la langue française, vol. 1. Copenhagen: Det Nordiske Forlag.

Piat, L. (1970). Dictionnaire français-occitanien. Aix-en-Provence: Edicioun Ramoun Berenguié.

Poplack, Shana (1979). Function and process in a variable phonology. Unpublished doctoral dissertation, University of Pennsylvania.

- (I981). Bilingualism and the vernacular. In B. Hartford, A. Valdman and C. Foster (eds.), Issues in International Bilingual Education: The Role of the Vernacular. New York: Plenum.

-(1984). Intergenerational variation in language use and structure in a bilingual context. In Charlene Rivera (ed.), An Ethnographic/Sociolinguistic Approach to Language Proficiency Assessment, 42-70. Clevedon, England: Multilingual Matters.

Robert, Paul (1972). Dictionnaire alphabétique et analogique de la langue française. Paris: Société du Nouveau Littré.

Sankoff, David (1979). VARBRUL 2S. Appendix B in S. Poplack, Function and process in a variable phonology. Unpublished Ph.D. dissertation, University of Pennsylvania. 
- , and Laberge, Suzanne (1978). The linguistic market and the statistical explanation of variability. In David Sankoff (cd.), Linguistic Variation. Models and Methods, 239-250. New York: Academic Press.

-, and Labov, William (1979). On the uses of variable rules. Language in Society 8 , $189-222$.

_, and Rousseau, Pascale (1983). Statistical evidence for rule ordering. In R. Rhodes (ed.), Evidence in Phonology. Ann Arbor: Karoma.

Saussure, Ferdinand (1967). Cours de linguistique générale. Paris: Payot.

Seutin, Émile (1975). Description grammaticale du parler de lîle-aux-Coudres. Montreal: University of Montreal Press.

Silva-Corvalán, Carmen (1983). Convergent and autonomous adaptations in the Spanish of Mexican-American bilinguals. Paper presented at El español en los Estados Unidos IV, Hunter College, C.U.N.Y., Oct. 7-8.

Spilka, Irène (1976). Assessment of second-language performance in immersion programs. The Canadian Modern Language Review 32, 543-561.

Straka, Georges (1965). Contribution à l'histoire de la consonne R en français. Neuphilologische Mitteilungen 66, 572-606.

Thibault, Pierrette (ed.) (1979). Le français parlé. Études sociolinguistiques. Edmonton: Linguistic Research.

- (1983). Équivalence et grammaticalisation. Unpublished doctoral dissertation, University of Montreal.

Toblers, Adolf, and Lommatzsch, Erhard (1925). Altfranzösiches Wörterbuch, vol. 1. Berlin: Weidmannsche Buchhandlung.

-, and Lommatzch, Erhard (1954). Altfranzösiches Wörterbuch, vol. 3. Wiesbaden: Steiner.

Trudgill, Peter (1976-1977). Creolization in reverse: reduction and simplification in the Albanian dialects of Greece. Transactions of the Philological Society.

-(1983). On Dialect. Oxford: Blackwell.

Vallières, Gaetan (1980). L'Ontario français par les documents. Montreal: Éditions Études Vivantes.

Wartburg, Walther von (1940). Französisches etymologisches Wörterbuch, vol. 2. Leipzig: Teubner.

-(1966). Französisches etymologisches Wörterbuch, vol. 12. Basel: Zbinden.

- (1969). Französisches etymologisches Wörterbuch, vol. 6. Basel: Zbinden.

Weinreich, Uriel (1968). Languages in Contact. The Hague: Mouton. 